\title{
Frequency of the Occurence of Methicilin Resistant Staphylococcus aureus Infections in Hyderabad, Pakistan
}

\author{
Nazir Ahmed Brohi ${ }^{*}$ and Agha Asad Noor \\ Institute of Microbiology, University of Sindh, Jamshoro, Sindh, Pakistan-76080. Pakistan \\ *Corresponding author E-mail: ahmednazeerbrohi@gmail.com \\ Received 12 April 2017, Revised 09 June 2017, Accepted 23 June 2017
}

\begin{abstract}
Staphylococcus aureus is a potential pathogen of hospital and community related infections. It secretes toxins or the enzymes as virulence factor of mild to severe infections and show resistance to beta-lactam antibiotic including penicillin, methicillin, oxacillin and now vancomycin that could alarm of equal risk factors of Methicillin Resistant Staphylococcus aureus (MRSA) infections in the patients. The survey report of 381 patients of Hyderabad, Pakistan was collected from March 2013 to June 2014 in which 176 cases were reported for Staphylococcus aureus in both genders of different age groups of 3-15 y kids, 16-45 y adults and 45-70 y olds, which showed 208 and 132 specimens Staphylococcus infection and 16 and 4 cases of MRSA infections in male and female patients, respectively whereas other 31 cases showed no infection. The laboratory diagnosis of the 200 samples from various hospitalized patients revealed the highest percentage of Methicillin Resistant Staphylococcus aureus MRSA in pus and post-operative wounds (17\%) followed by skin swabs $(10 \%)$, sputum $(7 \%)$ and blood $(0 \%)$. The observations revealed greater prevalence of MRSA infection in elderly age 16-45 years males than the females and other age groups. Antibiotic susceptibility test of 26 antibiotics revealed resistance (R-53\%), sensitive (S-39) and variable (V-7\%) sensitivity zones $(\mathrm{mm})$. Amplification of mecA gene was done using PCR reaction that revealed mecA gene bands up to 150-200 base pairs by test resistant strains.
\end{abstract}

Keywords: Staphylococcus aureus, Nosocomial infection, Antibiogram of MRSA, Methicillin resistance.

\section{Introduction}

The environment has many chemical impurities, which may affect the whole environment including the unicellular to multicellular organisms e.g. chlorinated dibenzodioxins and chlorinated dibenzofurans [1] and other biological impurities that include the presence of dead plants, dead animals and the minute microorganisms. These include the presence of Gram negative and Gram positive bacteria, fungi, viruses, protozoa in more or fewer numbers respectively. These biological pollutants causes very lethal to fatal diseases in humans and animals. Among these bacteria, Gram positive Staphylococci are potent pathogen that causes mild to fatal diseases.
Staphylococci are the main source of hospital acquired and community-acquired infections. These are resistant to many drugs and are known as multidrug-resistant staphylococci, which are being isolated from different environments such as water, food, mucosal surface of humans, domestic animals and hospital environments. These are environmentally universal and are the normal residents. In aquatic environments, staphylococci are found inhuman consumption and recreational water and also in the food manufacturing environment; more frequently those, which colonize the skin and the interior nares of food handlers [2]. The home environment exposes the Staphylococcus aureus and Methicillin 
Resistant Staphylococcus aureus (MRSA) from indoor bio-aerosols [3]. One more significant source of the home environment is the domestic animals [4-5]. In hospital environments these bacteria are also isolated from the surfaces of patients and healthcare personnel, hospital dust aerosols [6-8].

Staphylococcus aureus is a potent pathogen for a human [9] that is known to cause hospital-acquired infections and communityacquired infections [10]. MRSA infections are the major problems of the public health and known as a main cause of hospital acquired infections. Microscopic appearance is berry like round and arranged in the form of bunches. Their main habitats are nasal mucosa and skin and also colonize skin folds, hairline, perineum and navel [11-12].

They cause various mild to severe, complicated infections by secreting various virulent factors and recently show resistance to methicillin. Beside the resistance to methicillin, the MRSA is also resistant to other antibiotics. Vancomycin as a substitute of methicillin was also found resistant with vanA gene that was detected for vancomycin resistant strains $[10,13-15]$. The prevalence of antimicrobial resistance have alarmed in MRSA pathogens in serious infections. After the introduction of penicillin in the treatment the diseases frequency reduced till the production of beta-lactamase in Staphylococcus aureus that destroy the effect of penicillin, which led to the development of methicillin, but in 1961 the first strain of MRSA was reported [16]. The aim of the present study was to determine the frequency of MRSA infection and the antibiotic sensitivity of the clinical isolates against test antibiotics.

\section{Materials and Methods Epidemiological survey}

A data of more than 381 patients with Staphylococcal infections in both genders of different age groups was obtained by visiting various hospitals.

\section{Collection of samples}

Two hundred (200) samples of skin swabs and sloughs (78), blood (12) and pus and post-operative wounds (82) and sputum (28). Blood was collected by sterile syringes, inoculated into the Bec-Tec blood bottles. Pus and burns specimens were collected by sterile swabs and transported. Sputum was collected in a sterile wide mouthed bottle. All samples were inoculated separately in various media including blood in Bac-Tec bottles, kept for 5-7 days in Bac-Tec machine at $37^{\circ} \mathrm{C}$. Pus and burns specimens and sputum were inoculated on blood agar, chocolate agar, mannitol salt agar. One set of all plates were incubated aerobically at $37^{\circ} \mathrm{C}$ and the other set was incubated for partial anaerobic incubation at $10 \%$ $\mathrm{CO}_{2}$ incubatory for 24-48 hours.

\section{Characterization}

Cultural and microscopic observations were made from all specimens followed by biochemical studies by API 20 Staph system [17]. Antibiotic susceptibility test was performed by disc diffusion method as per CLSI standards.

\section{Polymerase chain reaction (PCR)}

Three step technique was used denaturing by high temperatures by a modified method in which heat $95^{\circ} \mathrm{C}$ was given for $4 \mathrm{~min}$ and later for 1 minute. The crude lysate mixture $(3.0 \mu \mathrm{l})$ was used as DNA template for subsequent PCR assays. Second annealing of the primers present in the reaction mixture to their complementary region in the template DNA and the third step includes polymerization by means of a DNA polymerase; also called Taq DNA polymerase. Amplification of $m e c A$ gene was done by PCR reaction in a thermal cycler (BioRed) [18]. Two primers were used such as

TGGCCAATACAGGAACAGCATA (forward), GGATAGCAGTACCTGAGCCA (reverse), GGCTCAGGTACTGCTATCCA (forward) and TGTAACGTTGTAACCACCCCA (reverse).

\section{(a)-Preparation of $50 \mu \mathrm{l}$ reaction mixture}

Two sets of the primer pairs were used. The following recipe was used for reaction mixture. 
Primer 1 Master Mix $25 \mu$ l, template $4 \mu$, primer forward $2 \mu 1(0.4 \mu \mathrm{M})$, primer reverse $2 \mu 1(0.4 \mu \mathrm{M})$, water $17 \mu 1$, total volume $50 \mu 1$. Master Mix contains PCR buffer, $\mathrm{MgCl}_{2}$, dNTPS, Taq DNA polymerase.

Primer 2 Master Mix $25 \mu$ l, template $4 \mu$, primer forward $2 \mu 1$, primer reverse $2 \mu 1$, water $17 \mu 1$, total volume $50 \mu 1$. In $25 \mu 1$ reaction mixture $12.5 \mu$ l of master mix (Thermo Scientific), $0.4 \mu \mathrm{M}$ of each forward and reverse primer was used. The thermal cycling conditions for amplifications were predenaturation $95^{\circ} \mathrm{C}$ for 4 minutes, denaturation $95^{\circ} \mathrm{C} 1$ minute, annealing $53^{\circ} \mathrm{C}$ for 40 seconds, extension $72^{\circ} \mathrm{C}$ for 1 minute, GOTO step $234 \mathrm{X}$, final extension $72^{\circ} \mathrm{C}$ for 5 minutes, hold at $4^{\circ} \mathrm{C}$. $1.5 \%$ agarose gel was run at 60 volts for 90 minutes.

\section{Results and Discussion}

Environmental pathogens normally spend their life largely outside the host including the human beings after invasion and cause disease at greater incidence [19]. Data of 381 patients was collected from March 2013 to June 2014 in which 176 cases were reported by Staphylococcus aureus in both genders different age groups such as kids (3-15Y), adults (16-45Y) and old aged (45-70Y). The prevalence of Staphylococcus aureus infection was reported in 208 males and 132 in females. The frequency of Staphylococcus aureus infection in male and female kids; adults and old aged persons was 62 and 42, 106 and 73, 36 and 21 (Fig. 1-2) including 16 and 4 cases of MRSA infection in both genders, respectively (Fig.3).

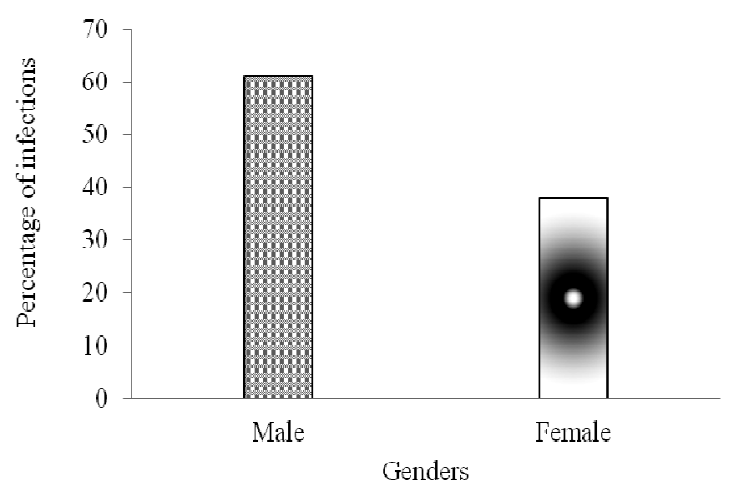

Figure 1. Percentage of Staphylococcus aureus infection in male and females

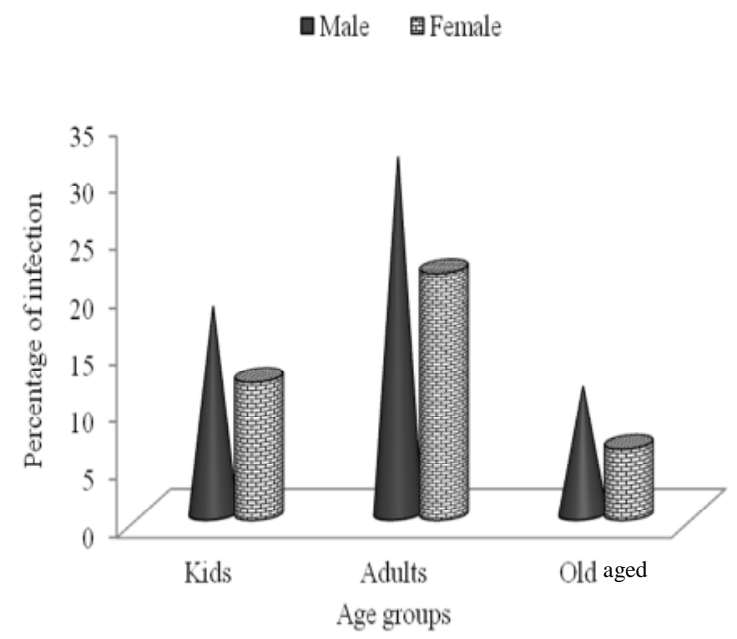

Figure 2. Determination of the percentage of Staphylococcus aureus infection in various age groups

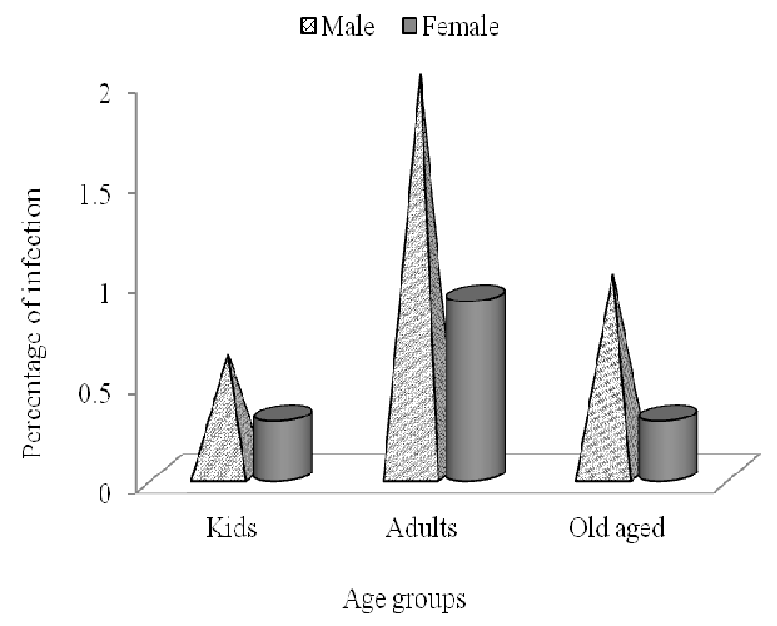

Figure 3. Determination of the percentage of MRSA infection in various age groups

Specimens of skin swabs and sloughs (78), blood (12) and pus and post-operative wounds (82) and sputum (28) of emerging patients including the specimens of hospitalized patients were collected for laboratory diagnosis. The highest percentage of MRSA was reported in pus and postoperative wounds $17 \%$ followed by skin swabs $10 \%$, sputum $7 \%$ and blood $0 \%$ from total 200 specimens (Fig. 4). The observations revealed that males of elderly age 16-45 years have the greater prevalence of MRSA infection as compared to the females and other age groups (Fig. 5). 


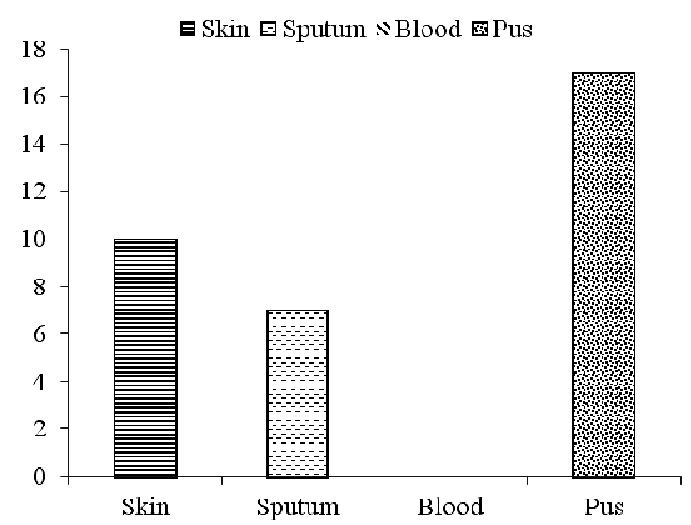

Figure 4. Total percentage of emerging MRSA

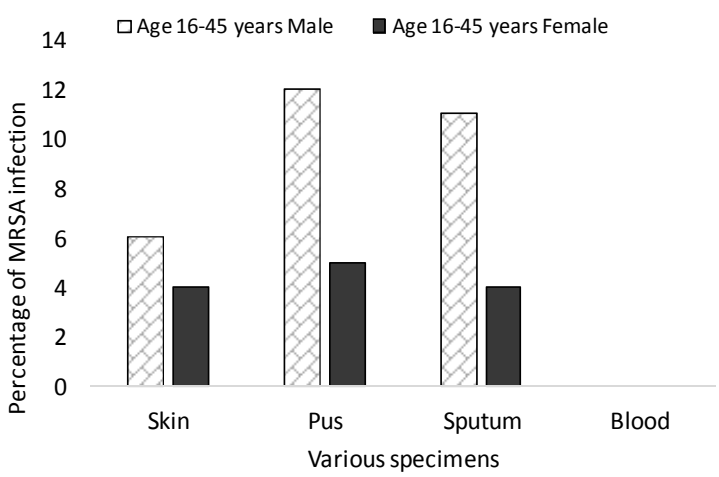

Figure 5. Determination of the percentage of MRSA in various age groups

The observation of colonial, morphological and biochemical characters of Staphylococcus aureus revealed medium to large colonies, large, convex, white colonies with a narrow zone of beta hemolysis on blood agar. Coagulase positive MRSA produced large, glistening, yellowish colonies with light yellowish zone around the colony on mannitol salt agar plate. Microscopically, they are Gram-positive Staphylococcus aureus ferment in glucose, lactose, sucrose, arabinose, maltose, mannose, galactose, urease, coagulase, oxidase, citrase whereas negative reactions in indole, methyl red, Vogus Proskauer, gel liquefaction and hydrogen sulfide production.

Antibiotic susceptibility test of 21 antibiotics revealed resistance (R-19\%), sensitive ( $\mathrm{S}-81)$ zones in millimeters by different isolates on Mueller-Hinton agar plates (Table-1, Fig. 6-7). Amplification of mecA gene was determined by PCR reaction in a thermal cycler
(BioRed). Two primers were used such as TGGCCAATACAGGAACAGCATA (forward), GGATAGCAGTACCTGAGCCA (reverse), GGCTCAGGTACTGCTATCCA (forward) and TGTAACGTTGTAACCACCCCA (reverse). The observation revealed that the test resistant strains showed mecA gene bands up to100-150 base pairs on agarose gel electrophoresis (plate 1-2).

Table 1. Antibiotic sensitivity test of MRSA isolates.

\begin{tabular}{|c|c|c|c|c|}
\hline \multirow[b]{2}{*}{$\begin{array}{l}\text { Name of the } \\
\text { Antibiotic }\end{array}$} & \multirow[b]{2}{*}{$\begin{array}{c}\text { Content } \\
\mu \mathrm{g}\end{array}$} & \multicolumn{3}{|c|}{ Susceptibility Pattern } \\
\hline & & $\begin{array}{c}\text { Resistance } \\
\%\end{array}$ & $\begin{array}{c}\text { Sensitivity } \\
\%\end{array}$ & $\begin{array}{c}\text { Intermediate } \\
\%\end{array}$ \\
\hline Cefoxitine & 30 & 87 & 11 & 2 \\
\hline Vancomycin & 30 & 11 & 89 & 0 \\
\hline Methicillin & 5 & 100 & 00 & 0 \\
\hline Oxacillin & 00 & 100 & 00 & 1 \\
\hline Lenizolid & 30 & 08 & 91 & 1 \\
\hline Teicoplanin & 30 & 01 & 97 & 2 \\
\hline Minocycline & 30 & 02 & 90 & 8 \\
\hline Clindamycin & 2 & 05 & 95 & 0 \\
\hline Rifampin & 5 & 07 & 91 & 2 \\
\hline $\begin{array}{l}\text { Quinupristin- } \\
\text { dalfopristin }\end{array}$ & 15 & 00 & 99 & 1 \\
\hline Ofloxacin & 5 & 16 & 84 & 0 \\
\hline Levofloxacin & 5 & 03 & 93 & 0 \\
\hline Ciprofloxacin & 5 & 36 & 62 & 2 \\
\hline Chloramphenicol & 30 & 03 & 96 & 1 \\
\hline Fusidic acid & 10 & 12 & 79 & 9 \\
\hline Moxifloxacin & 5 & 27 & 73 & 0 \\
\hline Erythromycin & 15 & 99 & 00 & 1 \\
\hline Tetracycline & 30 & 36 & 58 & 5 \\
\hline Gentamycin & 10 & 01 & 98 & 1 \\
\hline Kanamycin & 30 & 02 & 93 & 5 \\
\hline Tobramycin & 10 & 00 & 98 & 2 \\
\hline
\end{tabular}

口Resistance \% U Sensitivity \% Intermediate \%

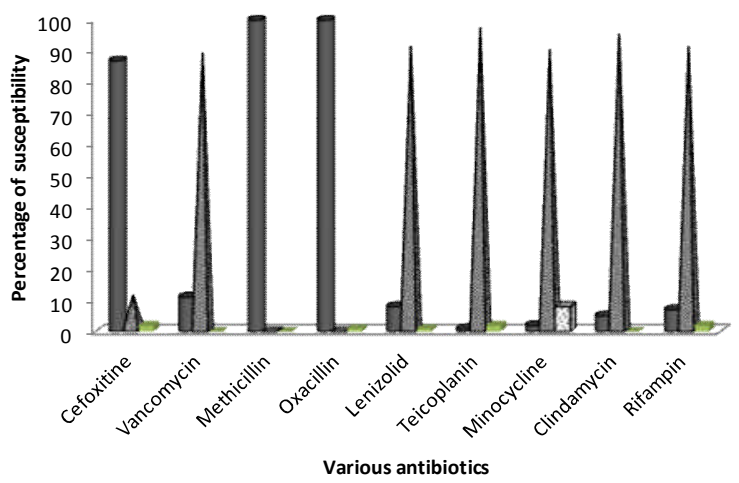

Figure 6. Determination of antibiotic pattern of MRSA isolates (a) 


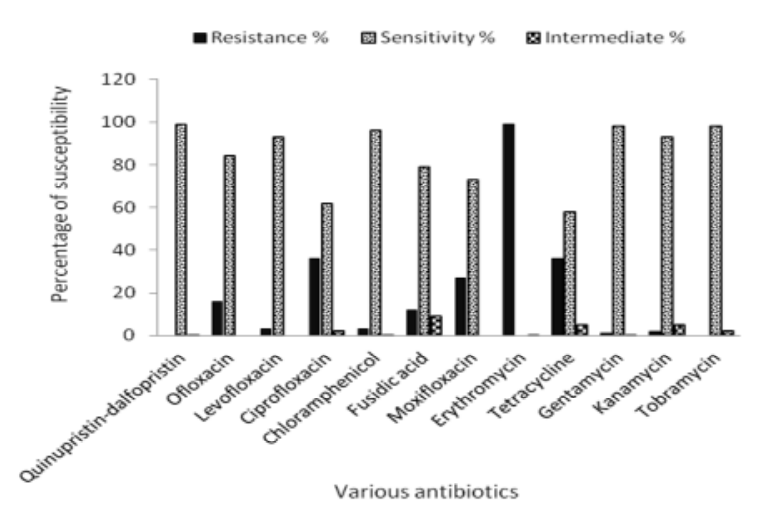

Figure 7. Determination of antibiotic pattern of MRSA isolates (b)

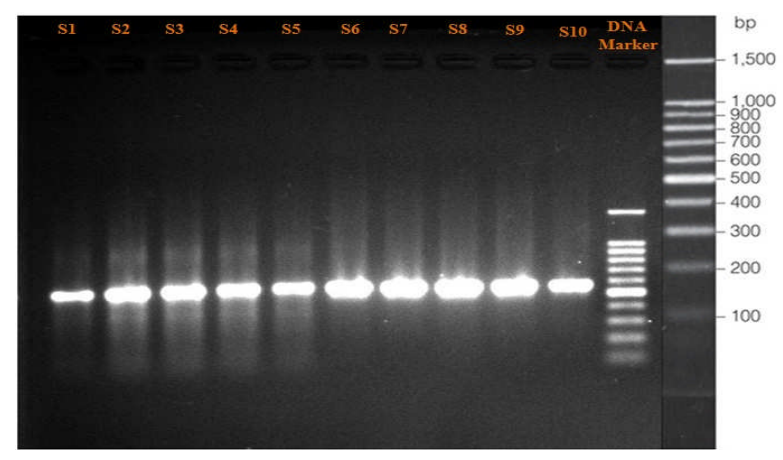

Plate 1. PCR amplification of mecA gene in MRSA isolates. Agarose gel electrophoresis of mecA gene: shows the amplified gene product (about $150 \mathrm{bp}$ )

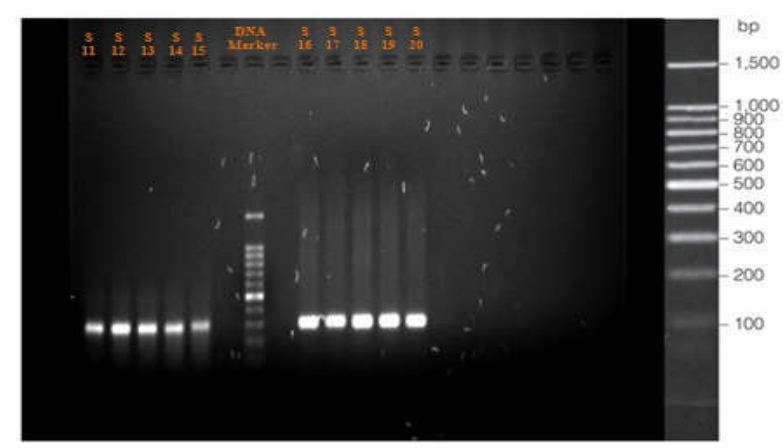

Plate 2. PCR amplification of mecA gene in MRSA isolates.

Agarose gel electrophoresis of mecA gene: shows the amplified gene product (about $150 \mathrm{bp}$ )

Since 1961, MRSA is worldwide pathogen with more incidence and death rates [20]. The strains of nosocomial infections were observed in 1980 [21]. According to the studies, the percentage of methicillin resistant Staphylococcus aureus prevalence is due to different plans of hospitals and the less capability of coupling with penicillin binding proteins for antibiotics with beta-lactam ring and the excess of penicillinase production [22]. The survey showed MRSA infections in males $60 \%$ in different age groups in the Hyderabad and around $40 \%$ in females of various age groups, respectively. This incidence rate may be due to the unhygienic measures in hospitals, more use of intravenous drugs, immunecompromised patients having hyperglycemia, lack of proper immune response. Our results are conferred with [23].

Staphylococcus aureus is a main G+ve with mortality rate. This death rate may be due to the attack of pathogenic strains with thehigh level of pathogenicity [24]. Staphylococcus aureus colonizes with the variation of age factor especially in kids of $10-12$ years $[21,25]$. The present study showed the increased percentage of MRSA in hospital-acquired, ICUs, burn wards. The results are accorded with reference to Rahman et al., and Scerri et al., [26-27]. The increased resistance could be due to insignificant selfmedication, untimely and arbitrary use of antibiotics. Staphylococcus aureus shows increasing resistance too many antibiotics and recently, the frequent use of antibiotics developed resistance among MRSA, which acquire genes of multiple resistances [28] against penicillin, methicillin, and cloxacillin due to the resistant genes [29].

In this study, the highest level of antimicrobial resistance in Staphylococcus aureus isolates were found in ampicillin, cloxacillin and penicillin, which may be due to the strain as observed by Okwu [30], whereas methicillin resistance and resistance to other beta lactam antibiotics is due to mecA gene and its expression [31]. Resistance to the other antibacterial agents may be due to discrete plasmids, transposable genetic elements and genomic islands. Methicillin resistance in Staphylococcus aureus endorses cross-resistance to other beta-lactum antibiotics [29]. Our observations from April 2013 to June 2014 showed $19 \%$ resistance and $81 \%$ sensitivity. This may be due to the strain to strain, abuse of antibiotics place to place and time factor. Our results are in accordance of [32-34]. In the present study, the aim was to identify risk factors of MRSA infections with community onset as studied by Boucher and Corey [35]. The observations showed that the increased close relationship 
relatives and discrete communities, lower level of social and economic conditions are high risk factor of antibiotic resistant Staphylococcus aureus. Animal contacts in both genders may also account for greater incidence of MRSA infections. These observations are in accordance of $[36,37]$.

\section{Conclusion}

It is concluded that MRSA infection specially reported in kids with greater incidence without mortality rate whereas the diagnosis of inpatients reported increased morbidity with less mortality rate showing $19 \%$ resistance, $81 \%$ sensitive zones pattern. It is also concluded that the test isolates were mainly resistant to methicillin, erythromycin, cefoxitine, oxacillin and highly sensitive to lenizolid, teicoplanin, minocycline, kanamycin, clindamycin, rifampin, gentamycin, quinupristin-dalfopristin, showing the sensitivity range from $90-99 \%$ whereas vancomycin $89 \%$. PCR observations concluded that the test strains have resistant $m e c A$ gene.

\section{Acknowledgement}

The author acknowledges Prof. Dr. Iqbal Chaudhary for his kind cooperation and permission for completion of the part of this work. The acknowledgement are also extended to Dr. Kamran Azeem and Junaid Ahmed Kori for their technical assistance in Jamil-ur-Rehman Genome Center at International Center for Chemical and Biological Science, HEJ research Institute, University of Karachi, Sindh, Pakistan.

\section{References}

1. J. E. Huff and J. S. Wassom, Int. J. Environ. Stud., 6 (1974) 13. doi:10.1080/00207237408709629

2. H. H. Abulreesh, Multidrug-Resistant Staphylococci in the Environment. Int. Conference on Biotechnology and Environment Management, IPCBEE, 18 (2011) 1.

3. A. Gandhara, L. C. Mota, C. Flores, H. R. Perez, C. F, Green and S. G. Gibbs, Environ. Health Prespect., $114 \quad$ (2006) 1859. https://doi:10.1289/ehp.9585.
4. M. J. Morgan, Antimicrob. Chemo., 62 (2008) 1181. https://doi:10.1093/jac/dkn405.

5. M. V. Boost, M. M. O'Donoghue and A. James, Epidemiol. Infect., 136 (2008) 953. https://doi:10.1017/S0950268807009326.

6. S. J. Dancer, S. J. Lancet, Infect. Dis., 8 (2008) 101. https://doi:10.1016/S1473-3099(07)70241-4.

7. G. L. French, J. A. Otter, K. P. Shannon, N. M. T. Adams, D. Watling and M. J. Parks, $J$. Hosp. Infect., 57 (2004) 31. https://doi:10.1016/j.jhin.2004.03.006.

8. D. O. Lis, J. Z. Pacha and D. Idzik, Am. J. Infect. Control., 37 (2009) 177. https://doi:10.1016/j.ajic.2008.09.013.

9. P. A. Trindade, J. A. McCulloch, J. A. Oliveira and E. M. Mamizuka, Braz. J. Infect. Dis., 7 (2003) 32. https://doi.org/10.1590/S1413$\underline{86702003000100005}$

10. M. T. Kuroda, O. I. Uchiyama, T. Baba, H. Yuzawa. I. Kobayashi, L. Cui, A. Oguchi, A. Ken-ichi, Y. Nagai, J. Lian, T.Ito, M. Kanamori, H. Matsumaru, A. Maruyama, H. Murakami, A. Hosoyama, Y. Mizutani-Ui, N. K. Takahashi, T. Sawano, I. Ryu-ichi, C. Kaito, K. Sekimizu, H. Hirakawa, S. Kuhara, S. Goto, J. Yabuzaki, M. Kanehisa, A. Yamashita, K. Oshima, K. Furuya, C. Yoshino, T. Shiba, M. Hattori, N. Ogasawara, H. Hayashi and K. Hiramatsu, The Lancet, 357 (2001) 1225. https://doi.org/10.1016/S01406736(00)04403-2.

11. A. M. Tristan, H. Bes, G. Meugnier, B. Lina, P. Bozdogan, M. Courvalin, M. E. Reverdy, M. C. Enright, F. Vandenesch and J. Etienne, Emerg. Infect. Dis., 13 (2007) 594. https://doi:10.3201/eid1304.061316.

12. N. Moremi, E. Stephen, E. Mshana, B. Kamugisha, B. Johannes, D. Kataraihya, D. Tappe, U. Vogel, F. E. Lyamuya and H. Claus, J. Infect. Dev. Ctries., 6 (2012) 620. https://doi.org/10.3855/jidc.2093

13. V. N. Kos, G. A. Desjardins, C. Gustavo, V. T. Andries, T. G. H. Matthew, G. Paul, L. P. Kelli, B. Kip, F. M. Emmanuel, W. Jennifer, F. Michael, L. Trevor, R. G. Steven, J. H Brian, B. Bruceand and S. G. Michael, Mbio. Asm. Org., 22, 3 (2012) 112. 
https://doi:10.1128/mBio.00112-12.

14. B. M. Limbago, A. J. Kallen, W. Zhu, P. Eggers, L. K. McDougal and V. S. Albrecht. J. Clin. Microbiol., 52 (2014) 998. https://doi:10.1128/JCM.02187-13.

15. A. Azimian, S. A. Havaei, H. Fazeli, M. Naderi, K. Ghazvini, S. M. Samiee, M. Soleimani and S. N. Peerayeh, J. Clin. Microbiol., 50 (2012) 3581. https://doi:10.1128/JCM.01727-1 2.

16. N. Buzaid, E. Abdel-Naser, I. Taher and K. S. Ghenghesh. J. Infect. Dev. Ctries., 5 (2011) 723. https://doi:10.3855/jidc.1701.

17. M. O. Ahmed, A. R. Abuzweda, M. H. Alghazali, A. K. Elramalli, S. G. Amri, Sh. A. Ezzeddin and Y. M. Abouzeed, Libyan J. Med., 5 (2010) 5230. https://doi:10.3402/ljm.v5i0.5230.

18. M. Askarian, A. Japoni, A. Zeinalzadeh, A. Alborzi and Z. A. Memish, Int. J. Infect. Dis., 13 (2009) 241. https://doi:10.1016/j.ijid.2008.11.026.

19. N. A. Brohi, A. A. Noor, S. B. Memon and S. A. Tunio, Pak. J. Anal. Environ. Chem., 17 (2016) 170. https://doi.org/10.21743/pjaec.v17i2.268.

20. G. F. Webb, M. A. Horn, E. M. D'Agata, R. C. Jr. Moellering and S. Ruan, J. Biol. Dyn. 4 (2010) 115. https://doi:10.1080/17513750903026411.

21. N. Parvez, C. Jinadatha, R. Fader, T. W. Huber, A. Robertson, D. Kjar and L. K. Cornelius, South Med. J., 103 (2010) 1084. https://doi:10.1097/SMJ.0b013e3181f69235.

22. F. A. Orrett and M. Land. BMC Infectious Dis., 6 (2006) 83. https://doi:10.1186/1471-2334-6-83.

23. C. M. Fankhauser, J. Schrenzel, D. Pittetand, S. Harbarth, BMC Proceedings 5 (2011) 5. https://doi:10.1186/1753-6561-5-S6-P5.

24. R. Prabhakara, O. Foreman, R. De Pascalis, G. M. Lee, R. D. Plaut, S. Y. Kim, S. Stibitz, K. L. Elkins and T. J. Merkel. Infect. Immunity, $81 \quad$ (2013) 1306. https://doi:10.1128/IAI.01304-12.

25. H. J. Huh, E. S. Kim and S. L. Chae, Ann. Lab. Med., 32 (2012) 407. https://doi:10.3343/alm.2012.32.6.407.
26. S. Rahman, S. Mumtaz, A. J. Mufti, S. H. Shah and M. Rahman, J. A. Med. Coll. Abbottabad., 23 (2013) 99. https://www.ncbi.nlm.nih.gov/pubmed/2283 $\underline{0159}$.

27. J. Scerri, S. Moneckeand, M. Borg, J. Epidemiol. Global Health, 3 (2011) 165. https://doi:10.1016/j.jegh. 2013.05.003.

28. K. B. Anand, P. Agrawal, S. Kumar and K. Kapila, Indian. J. Med. Microbiol., 27 (2009) 27.

http://www.ijmm.org/text.asp?2009/27/1/27/ 45164.

29. M. Bilal, A. Janan, Irfanullah and M. Ahmad, Pak. J. Surg., 30 (2014) 301. http://www.pjs.com.pk/journal.pdfs/oct-dec 14/301.pdf.

30. M. Okwu, S. Bamgbala and W. Aborisade, $J$. Nat. Sci. Res., 2 (2012) 61.

31. L. C. Gelatti, R. R. Bonamigo, F. M. Inoue, M. S. Carmo, A. P. Becker, F. M. Castruccm A. C. Pignatariand and P. A. D. Azevedo, Revista da Sociedade Brasileira de Medicina Tropical, 46 (2013) 8. https://dx.doi.org/10.1590/0037$\underline{868213022013}$

32. K. A. Prates, A. M. Torres, L. B. Garcia, S. F. Ogatta, C. L. Cardoso and M. C. Tognim, Braz. J. Infect. Dis., 14 (2010) 316. https://doi.org/10.1016/S14138670(10)70064-7.

33. I. Kaddora. Marshall University., (2010) 1. http://mds.marshall.edu/etd/100/.

34. F. J. Kaleem, U. A. Hassan, M. Omair, A. Khalid and Roz Uddin, Iran J. Microbiol., 2 (2010) 143.

https://www.ncbi.nlm.nih.gov/pmc/articles/P MC3279784/.

35. H. W. Boucher and G. R. Corey, Clin. Infect. Dis., 46 (2008) S344. https://doi.org/10.1086/533590.

36. A. J. De Neeling, M. J. Van, D. Broek and E. C. Spalburg, Vet Microbiol., 122 (2007) 366. http://doi.org/10.1016/j.vetmic.2007.01.027.

37. X. W. Huijsdens, B. J. van Dijkem, E. Spalburg, M. G. van Santen-Verheuvel, M. E. Heck, G. N. Pluister, A. Voss, W. J. Wannet and A. de Neeling. Ann. Clin. Microbiol. Antimicrob., 5 (2006) 26. https://doi:10.1186/1476-0711-5-26. 